\title{
Squamous cell carcinoma of scrotum mimicking as scrotal abscess
}

\author{
Gaurav Garg, Ashish Sharma, Ajay Aggarwal, Satyanarayan Sankhwar
}

Department of Urology, King George's Medical University, Lucknow, Uttar-Pradesh, India

Correspondence to Dr Ashish Sharma, ashishuc343@gmail.com

Accepted 20 June 2018

\section{DESCRIPTION}

A 60-year-old man was referred to our urology department with complaints of non-healing scrotal wound for the last three months. He initially presented to a primary care centre with complaints of painful scrotal swelling and discharging scrotal wound for 15 days. The discharge card given to the patient mentioned that the patient was provisionally diagnosed as scrotal abscess and underwent incision and drainage. On local examination, an irregular appearing, ulcerated scrotal wound with everted margins was present (figure 1). The local examination of inguinal region and general physical examination was normal. Routine blood/ urine investigations were within normal limits. Wedge biopsy from wound margins was performed under local anaesthesia. The histopathology came as a surprise to us as it revealed proliferating squamous epithelial cells disposed of as nests and solid masses suggestive of well-differentiated squamous cell carcinoma (figure 2). Further workup including contrast-enhanced CT abdomen/pelvis and chest X-ray revealed no obvious evidence of metastasis. After proper patient counselling and due consultation from surgical oncologist, radical scrotectomy, bilateral simple orchiectomy and reconstruction with local thigh flap was done. Histopathological examination demonstrated the presence of

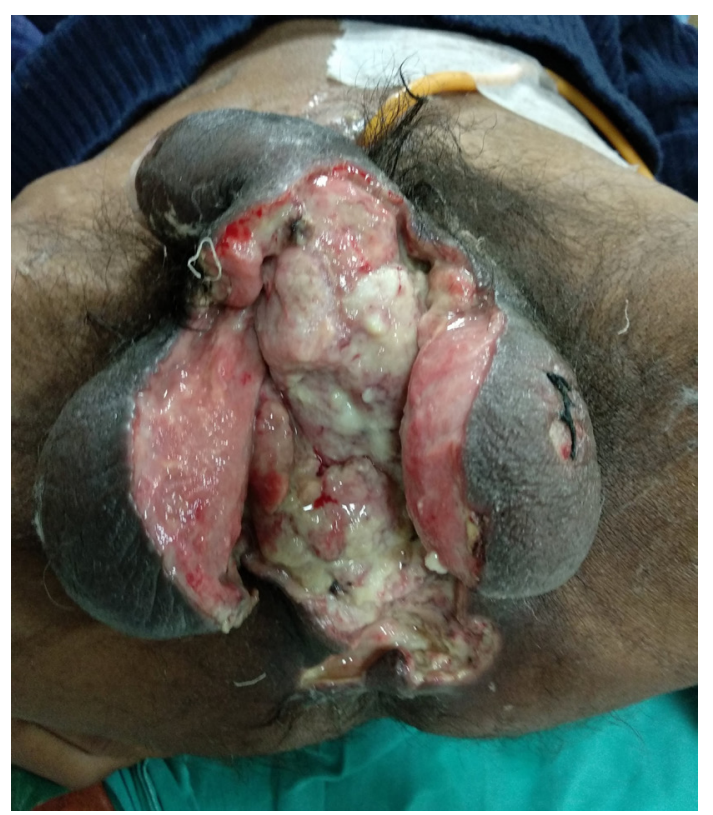

Figure 1 Clinical image of the scrotum showing an irregular appearing, ulcerated scrotal wound with everted margins.

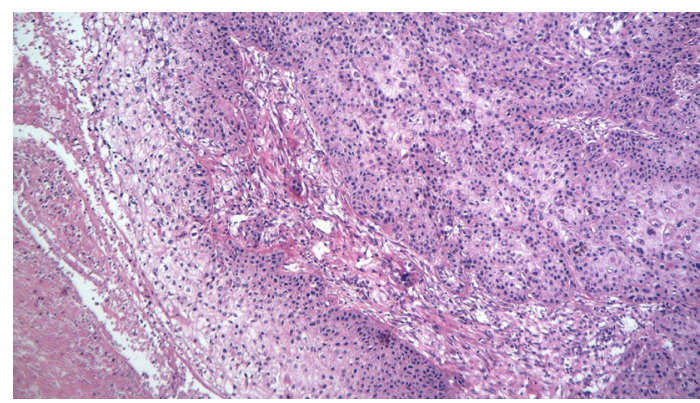

Figure 2 Histopathological image showing proliferating squamous epithelial cells disposed of as nests and solid masses.

well-differentiated squamous cell carcinoma with involvement to deep dermal soft tissues. There was no involvement of testis or spermatic cord by the tumour and all resected margins were negative. The patient is doing fine at 6 months follow-up with no evidence of recurrence/distant metastasis. Primary squamous cell carcinomas of scrotum are very rare tumours that usually present as single painless and slowly growing lesions. ${ }^{1}$ In some cases due to a rapid increase in the lesion size, superficial skin ulceration and bleeding can occur and the area may get infected. ${ }^{12}$ The usual risk factors for the development of squamous cell carcinoma of scrotum include exposure to chemicals like arsenic, paraffin, tar, petroleum wax and human papillomavirus. ${ }^{3}$ Both scrotal cancer and a scrotal abscess can present with similar features like scrotal swelling, skin ulceration and wound discharge. A high index of suspicion is indicated to rule out malignancy in case of a long-standing scrotal swelling presenting in an elderly man even if usual risk factors are not present. If a scrotal lesion shows features like a sudden increase in size, irregular consistency, associated inguinal lymphadenopathy and if it fails to

\section{Learning points}

Primary squamous cell carcinoma of the scrotum is very rare.

- Both scrotal abscess and scrotal carcinoma can have similar presentation including scrotal swelling, skin ulceration and bleeding.

- An early excisional biopsy must be done to rule out malignancy in case of elderly men if a scrotal abscess shows suspicious features such as sudden increase in size, irregular consistency and associated inguinal lymphadenopathy and if wound fails to heal timely. 


\section{Images in...}

heal then an early excisional biopsy must be performed to rule out malignancy.

Contributors GG: concept, design, supervision, processing, writing manuscript and critical analysis. AS: concept, design, supervision, processing, writing manuscript and critical analysis. AA: supervision, processing, writing manuscript and critical analysis. SS: concept, supervision, writing manuscript and critical analysis.

Funding The authors have not declared a specific grant for this research from any funding agency in the public, commercial or not-for-profit sectors.

Competing interests None declared.
Patient consent Obtained.

Provenance and peer review Not commissioned; externally peer reviewed.

\section{REFERENCES}

1 Casasola Chamorro J, Gutiérrez García S, de Blas Gómez V. Scrotal carcinoma. Arch Esp Urol 2011;64:541-3.

2 Azike JE. A review of the history, epidemiology and treatment of squamous cell carcinoma of the scrotum. Rare Tumors 2009;1:47-9.

3 Graves RC, Flo S. Carcinoma of the scrotum. J Urol 1940;43:309-32.

Copyright 2018 BMJ Publishing Group. All rights reserved. For permission to reuse any of this content visit

http://group.bmj.com/group/rights-licensing/permissions.

BMJ Case Report Fellows may re-use this article for personal use and teaching without any further permission.

Become a Fellow of BMJ Case Reports today and you can:

- Submit as many cases as you like

- Enjoy fast sympathetic peer review and rapid publication of accepted articles

- Access all the published articles

Re-use any of the published material for personal use and teaching without further permission

For information on Institutional Fellowships contact consortiasales@bmjgroup.com

Visit casereports.bmj.com for more articles like this and to become a Fellow 